\title{
Commercial Banks Financing Priority Sector: An Impetus to Economy (A Study of Problems and Prospects)
}

\author{
Dr Kewal Kumar ${ }^{1}$ and Atul Gambhir ${ }^{2}$ \\ Principal ${ }^{1}$ and Assistant Professor ${ }^{2}$,Institute of Management and Technology Kashipur, Uttarakhand, India.
}

\begin{abstract}
Priority sector lending is a scheme guided by govt. and RBI to commercial banks about obligatory deployment of credit to preferred and desired sectors and sections of the economy. Preferred sectors and sections are agriculture, small scale industries, small businessman, education, housing finance etc. and sections of the society are below income persons. The object behind PSL (Priority Sector Lending) is equitable and sustainable economic development at desired direction. To attain the said objectives, banks were nationalized in India in1969. Since in this scheme banks were entrusted to fulfill some targets and sub-targets of deployment of credit such as 40 per cent for domestic banks and 32 per cent for foreign banks was fixed for priority sector lending of their total advances. Though public sector banks have progressed remarkably and achieved their targets, private sector banks are lagging behind in this respect.Now on invent of some new schemes like PSL banks in India are shaping the economy and are providing an impetus to the economy. Despite various qualities and goodness, the scheme is not free from problems. Author has made an attempt through this treatise to highlight these problems and suggested some ideas for effective formation of the scheme. The over all future of this scheme in India is bright but needs a regular review process.
\end{abstract}

Keywords: Credit deployment, Micro credit, Nationalization, Non-performing assets, vital sectors of the economy, Weaker sections.

\section{Introduction}

Priority means to give preference and privilege. The concept of priority sector lending (PSL) is mainly intended to ensure that assistance from the banking system flows in an increasing manner to those persons and sectors of the economy which, through accounting for a significant proportion of the national product, have not received adequate support of the institutional finance in the past .Under the new banking policy, stress is laid on the weaker and under privilege groups and vital sector as priority sectors.

1.1 Vital sectors of the economy getting priority under the scheme of PSL

- Agriculture -both direct and indirect finance.

- Small scale industries.

- Small road and water transport operators.

- Professional and self-employed persons.

- Setting up of industrial estates.

- Education.

- Indirect finance to other priority sectors-loans on scheduled castes and scheduled tribes, corporations, organizations.

- Housing loans to scheduled castes and scheduled tribes (SC/ST) and weaker sections.

- Consumption loans.

- To boast the country export, export sector is treated as a quasi priority sector.

1.2 Weaker sections under PSL

The concept of weaker sections refer to all persons who became suppressed, depressed, and oppressed because of socio-political, socio-economic or socio-religious reasons. Weaker section include:

- Small and marginal farmers with land holding of 5 acres and less.

- Landless labourers.

- Tenant farmers and share croppers.

- Artisans, village and small industries.

- Beneficiaries of the integrated rural development program(IRDP).

- Scheduled castes and scheduled tribes.

- Beneficiaries different rates of interest schemes. 


\subsection{Directives issued by RBI}

The RBI issued certain directives to the banks regarding priority sector lending.

- Priority sector lending should constitute $40 \%$ aggregate bank credit.

- Out of the priority sector advances, at least $40 \%$ should be provided to agriculture.

- Direct advances to the weaker sections in agriculture and allied activities in rural sector should form at least $50 \%$ of the total direct lending to agriculture.

- The advances to rural artisans, village craftsmen and cottage industries should be at least $12.5 \%$ of the total advances to the small scale industries.

\section{Objectives Of The Study}

Our treatise is based on the following objectives

- To present an overview on priority sector lending in India.

- To review the present policy framework of priority sector lending.

- To present a conceptual study of various programs and schemes under PSL.

- To know the various problems and provide some suggestions to strengthen this system of lending and future prospects of priority sector lending in India.

- To provide an awareness to general public about priority sector lending and its benefits to the weaker section.

\section{Methodology And Research Design}

The nature of our study is perspective and analytical. The universe of this study is Indian banking sector. To fulfill the above mention objectives, secondary data is used which is taken from the various reports published by Reserve bank of India (RBI), National bank for agricultural and rural development (NABARD), Central statistical organization

, Economic survey of India and lead bank report. Data are classified and tabulated in such manner so that analysis and interpretation can easily be attained.

\subsection{Differential Rates Of Interest Scheme (DRI)}

\section{Various Credit Schemes Under Priority Sector}

This scheme was launched in India in 1972 for public sector banks to extend bank credit to the weaker section at concessional rate of interest at $4 \%$ p.a. according to new guidelines issued by BBI, banks have to deploy $1 \%$ of their total advances to the weaker section of society and further to set aside $40 \%$ of their advances meant under DRI scheme for beneficiaries belong in to the scheduled castes and scheduled tribes. The eligibility foe assistance under this scheme is now Rs.6400 annual family income in rural areas and Rs.7200 per annum per family in urban areas. The private sector banks can also participate in this scheme on a voluntary basis. Under the DRI scheme, the banks are directed by the Reserve bank to finance:

- Scheduled castes and scheduled tribes and other engaged on the modest scale in agriculture and allied activities.

- The physically-handicapped people on the modest scale by offering loans for cottage and rural industries and vocations like sewing garments, making reasonably cheap edibles, running way side tea stalls, basketmaking etc.

- People engaged in elementary processing of forest products.

- Village artisans in the decentralized sector.

\subsection{Education Loans}

Student loans in India (popularly known as Education loans) have become a popular method of funding higher education in India with the cost of educational degrees going higher. The spread of self-financing institutions (which has less to no funding from the government) for higher education in fields of engineering, medical and management which has higher fees than their government aided counterparts have encouraged the trend in India. Most large public sector and private sector banks offer educational loans.Under section 80(e) of the Indian income tax act, a person can exempt the amount paid against the interest of the education loan - either for self or for his/her spouse or children - for eight years from the year (s)he starts to repay the loan or for the duration the loan is in effect, whichever is lesser. Education loan is becoming popular day by day because of rising fee structure of higher education. It came into existence in 1995 started by SBI Bank and after that many banks started offering student loans. At present, the model education loan scheme allows loan up to Rs 10 lakh for students in India and up to Rs 20 lakh for the students studying abroad. For a loan up to Rs 4 lakh, coobligation of parents is required and for loans above Rs 4 lakh and up to Rs 7.5 lakh, co-obligation of parents together with collateral security in the form of suitable third party guarantee is required. In case of loans above Rs 7.5 lakh, co-obligation of parents together with tangible collateral security of suitable value, along with the 
assignment of future income of the student for payment of installments is necessary. The rate of interest for loans up to Rs 4 lakh is BPLR and for loans above Rs 4 lakh, one per cent more than BPLR is charged by the banks.

\subsection{Housing Loans}

Loans up to Rs. 15 lakh for construction of houses by individuals, (excluding loans granted by banks to their own employees) and loans given for repairs to the damaged houses of individuals up to Rs. 1 lakh in rural and semi-urban areas and up to Rs.2 lakh in urban areas. Assistance up to Rs. 1.25 lakh per housing unit given to any governmental agency/ nongovernmental agency (approved by the NHB for the purpose of refinance) for construction/ reconstruction of houses or for slum clearance and rehabilitation of slum dwellers.

\subsection{Micro Credit}

Provision of credit and other financial services and products of very small amounts not exceeding Rs. 50,000 per borrower to the poor in rural, semi-urban and urban areas, either directly or through a group mechanism, for enabling them to improve their living standards, will constitute micro credit.

\subsection{Agriculture (Direct and Indirect Finance)}

Direct finance to agriculture shall include short, medium and long term loans given for agriculture and allied activities directly to individual farmers, Self-Help Groups (SHGs) or Joint Liability Groups (JLGs) of individual farmers without limit and to others (such as corporate, partnership firms and institutions) up to Rs.20 lakh, for taking up agriculture/allied activities. Indirect finance to agriculture shall include loans given for agriculture and allied activities.

\subsection{Small Scale Industries (Direct and Indirect Finance)}

Direct finance to small scale industries (SSI) shall include all loans given to SSI units which are engaged in manufacture, processing or preservation of goods and whose investment in plant and machinery (original cost) excluding land and building does not exceed the amounts specified in Section I, appended. Indirect finance to SSI shall include finance to any person providing inputs to or marketing the output of artisans, village and cottage industries, handlooms and to cooperatives of producers in this sector.

\subsection{Small Business / Service Enterprises}

shall include small business, retail trade, professional \& self employed persons, small road \& water transport operators and other service enterprises as per the definition given in Section I and other enterprises that are engaged in providing or rendering of services, and whose investment in equipment does not exceed the amount specified in Section I, appended.

\section{Targets/Sub-Targets Set By Rbi}

The targets and sub-targets set under priority sector lending for domestic and foreign banks operating in India are furnished below

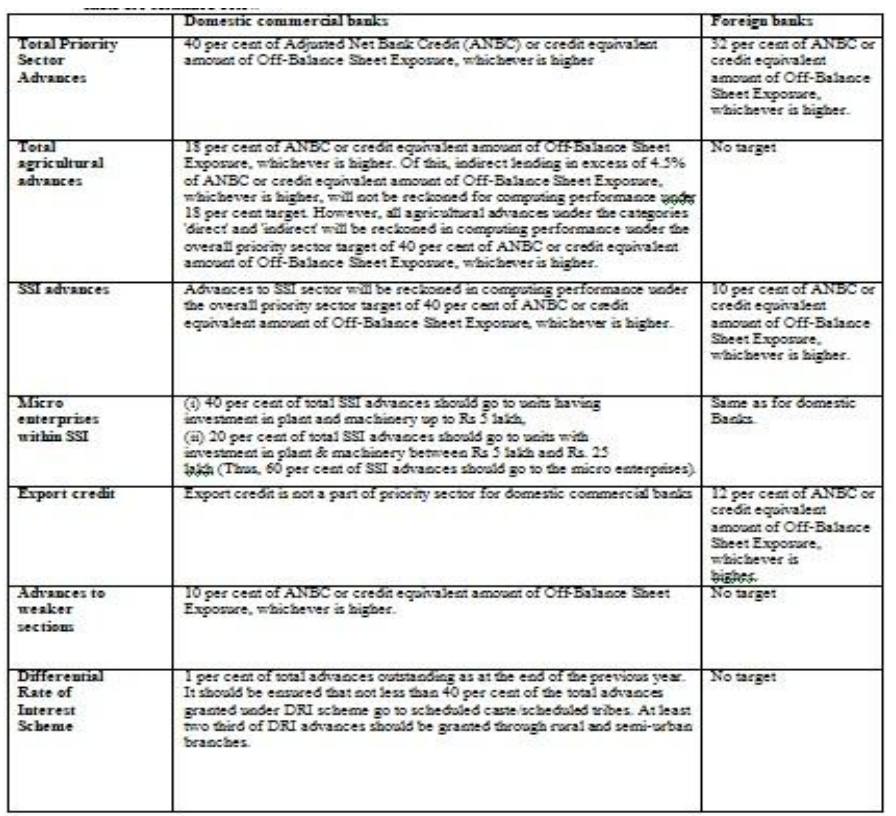

Source: Based on RBI's report on trend and progress of banking in India.

ANBC: Adjusted net bank credit. 
Table-1: Deployment of Bank Credit to Priority Sector in India

\begin{tabular}{|c|c|c|c|c|c|c|c|c|c|c|c|}
\hline S.N & $\begin{array}{l}\text { Priority } \\
\text { sector }\end{array}$ & $\begin{array}{l}\text { Mar } \\
1997\end{array}$ & $\begin{array}{l}\text { Mar } \\
1998\end{array}$ & $\begin{array}{l}\text { Mar } \\
1999\end{array}$ & $\begin{array}{l}\text { Mar } \\
2000\end{array}$ & $\begin{array}{l}\text { Mar } \\
2001\end{array}$ & $\begin{array}{l}\text { Mar } \\
2002\end{array}$ & $\begin{array}{l}\text { Mar } \\
2003\end{array}$ & $\begin{array}{l}\text { Mar } \\
2004\end{array}$ & $\begin{array}{l}\text { Mar } \\
2005\end{array}$ & $\begin{array}{l}\text { Mar } \\
2006\end{array}$ \\
\hline 1 & $\begin{array}{l}\text { Total } \\
\text { bank credit }\end{array}$ & $\begin{array}{l}2,58,99 \\
1 \\
(100)\end{array}$ & $\begin{array}{l}3,00,2 \\
83 \\
(100)\end{array}$ & $\begin{array}{l}3,42,0 \\
12 \\
(100)\end{array}$ & $\begin{array}{l}4,00,8 \\
18 \\
(100) \\
\end{array}$ & $\begin{array}{l}4,69,1 \\
53 \\
(100)\end{array}$ & $\begin{array}{l}5,36,7 \\
27 \\
(100)\end{array}$ & $\begin{array}{l}6,69,5 \\
34 \\
(100)\end{array}$ & $\begin{array}{l}7,64,3 \\
83 \\
(100)\end{array}$ & $\begin{array}{l}10,40, \\
909 \\
(100)\end{array}$ & $\begin{array}{l}14,45,8 \\
37 \\
(100)\end{array}$ \\
\hline 2 & $\begin{array}{l}\text { Agriculture } \\
\& \text { allied }\end{array}$ & $\begin{array}{l}31442 \\
(12.1)\end{array}$ & $\begin{array}{l}34869 \\
(11.6)\end{array}$ & $\begin{array}{l}39634 \\
(11.6)\end{array}$ & $\begin{array}{l}44381 \\
(11.1)\end{array}$ & $\begin{array}{l}51922 \\
(11.0)\end{array}$ & $\begin{array}{l}60761 \\
(11.3)\end{array}$ & $\begin{array}{l}73,51 \\
8 \\
(10.9) \\
\end{array}$ & $\begin{array}{l}90,54 \\
1 \\
(11.8)\end{array}$ & $\begin{array}{l}1,25,2 \\
50 \\
(12.0)\end{array}$ & $\begin{array}{l}1,72,27 \\
9 \\
(11.9)\end{array}$ \\
\hline 3 & $\begin{array}{l}\text { Small scale } \\
\text { industries }\end{array}$ & $\begin{array}{l}35944 \\
(13.9)\end{array}$ & $\begin{array}{l}43508 \\
(14.5)\end{array}$ & $\begin{array}{l}48483 \\
(14.2)\end{array}$ & $\begin{array}{l}52814 \\
(13.2)\end{array}$ & $\begin{array}{l}56002 \\
(11.9)\end{array}$ & $\begin{array}{l}57199 \\
(10.6)\end{array}$ & $\begin{array}{l}60,39 \\
4 \\
(9.0)\end{array}$ & $\begin{array}{l}65,85 \\
5 \\
(8.6)\end{array}$ & $\begin{array}{l}74,58 \\
8 \\
(7.2)\end{array}$ & $\begin{array}{l}90,239 \\
(6.2)\end{array}$ \\
\hline 4 & $\begin{array}{l}\text { Other } \\
\text { priority } \\
\text { sector }\end{array}$ & $\begin{array}{l}17494 \\
(6.8)\end{array}$ & $\begin{array}{l}21130 \\
(7.0)\end{array}$ & $\begin{array}{l}26494 \\
(7.7)\end{array}$ & $\begin{array}{l}34632 \\
(8.6)\end{array}$ & $\begin{array}{l}46490 \\
(9.9)\end{array}$ & $\begin{array}{l}57299 \\
(10.7)\end{array}$ & $\begin{array}{l}77,69 \\
7 \\
(11.6)\end{array}$ & $\begin{array}{l}1,07,4 \\
38 \\
(14.0)\end{array}$ & $\begin{array}{l}1,81,6 \\
38 \\
(17.4)\end{array}$ & $\begin{array}{l}2,47,37 \\
9 \\
(17.1)\end{array}$ \\
\hline
\end{tabular}

Source:RBI's report on trend and progress of banking in India

\section{Problems And Shortcoming Of Psl In India}

Despite a remarkable growth of priority sector lending by the commercial banks in recent years, some basic problems and shortcomings are found in this system during the course of study.

6.1 Unduly broad based classification of priority sector- Under the existing system, the classification of priority sector advances has remain broad-based, so that even big borrower could avail of the benefits of priority treatment provided by the banks.

6.2 Need to identify priority sectors appropriately- It is necessary to identify appropriate sectors with in the priority sectors on a rational basis. So that preferential treatment can be availed by defined and targeted persons.

6.3 Need to examine the viability of project under priority sectors- while granting credit to artisans, cottage industries, etc., the bank should also examine the viability of the marketability point of view if not so this loan will poses the problem of recovery for the banks.

6.4 Efficacy: There is always the problem of ensuring the effective end use of the loans given to the priority sectors.

6.5 Need to re-look at target- There is a time need to review the target fixed at the inception of scheme, for example $40 \%$ of total bank credit to priority sector and other sub-targets. At present time it should be revised on rational basis.

6.6 The problem of bad debt- Another problem is the problem of bad debt arising from indiscriminate lending by banks, keeping an eye on the fulfillment of the stipulated targets.

\section{Suggestions, Future Prospects And Conclusion-}

Quantitatively, public sector banks have progressed well in priority lending but their qualitative aspect is to be evaluated. For instance over dues, bad debts and NPA have been a serious problems faced by the bank in respect of advances made to the weaker sections of society private sector banks are lagging behind in PSL progress. There is a need to revise time to time the targets and sub-targets set by RBI for this scheme. Eligibility for SSI and SSB and weaker section should redefined on rational basis. Projects under PSL should effectively checked and evalued for the porpuse of viability and efficacy. For under recovery of dues and NPA (Non Performing Assets) in case of weaker section advances, suggestion is, - A special model like micro financing (Bank linkage self help group) be formed, as in this model recovery rate is nearly $95 \%$. Projects for small scale for infrastructure development in villages like road construction, electricity, drinking water and primary education projects should be preferred under priority sector lending and special sub-targets be set for these schemes. Overall impact of priority sector lending scheme is positive. Banks are now deploying credit in desired direction and providing an impetus to the rural economy. Future prospect of the PSL is bright in India.

\section{References-}

[1]. Mithani, D.M. Money, Banking, 'International, Trade And public Finance' - Himalaya Publishing House Bombay.

[2]. Niranjana. S, and Anubumani, V 2002 'Social Objectives And Priority Sector Lending, Banking And Financial Sector Reform In India', Deep And Deep Publications, PP-231.

[3]. Patel, S.G.1996, 'Role of Commercial Banks' Lending to Priority Sector in Gujarat-An Evaluation, Finance India' X (2):389-393.

[4]. RBI Internal Working Group (2005) Priority Sector Lending, Rural Planning and Credit Department Central Office, RBI, Mumbai, September.

[5]. RBI's report on trend and progress of banking in India (various issues).

[6]. Sooden, M and Kumar, S. 2007. Priority Sector Lending in Post Reform Period, Finance India, December, XXI (4): 1389-1404

[7]. Statistical Tables Relating to Banks in India (Various Issues), Reserve Bank of India, Mumbai. URL: (www.rbi.org.in). 